A $\mathrm{N}$ idea first put forward by Zionist visionary Theodore Herzl 73 years ago, and then brought up again four decades later by an American soil conservationist, Walter Clay Lowdermilk, may soon, at long last, be implemented.

Herzl, Lowdermilk and others have advocated the construction of a canal (or tunnel) through which seawater would flow from the Mediterranean to the Dead Sea so that the difference in level of $400 \mathrm{~m}$ could be exploited for electricity generation.

Advocates came and went, but only recently, prompted by the energy crisis, did the government appoint a committee seriously to consider the possible implementation of such a scheme. The committee, headed by Bar-Ilan Professor Shlomo Eckstein, had before it a plan for building a $75-\mathrm{km}$ tunnel which would bring Mediterranean water to a reservoir in the Judean Desert highlands overlooking the Dead Sea, from which it would be 'dropped' through turbines with an installed capacity of $300 \mathrm{MW}$.

The next stage, if the Eckstein committee's recommendations are accepted by the government, will be a 'prefeasibility study', including test drillings at various places along the proposed route.

According to present estimates, the project will require 10 years to complete and cost more than $\$ 200$ million (at present prices). In operation, it will not only increase electricity supplies but also replenish the rapidly evaporating waters of the Dead Sea, from which large quantities of potash, bromine and other valuable minerals are extracted. Traditional sources of replenishment, particularly the inflow from the Jordan River, have gradually dried up as more and more sweet water is being syphoned off upstream by Israelis and Jordanians for irrigation purposes.

There is, however, a limit to the amount of seawater that can be poured into the Dead Sea if it is not to overflow. Thus the turbines can only be activated for some 2,700 hours a year. As conceived at present, the flow would be scheduled to coincide with periods of peak demands for electricity, when hydroelectric power would supply $10 \%$ of Israel's estimated electricity requirements (in 10 years' time). Should other power stations be put temporarily out of action, however, the turbines could be kept in operation for an extended period, after which they would have to be shut down for two or three years while the Dead Sea 'dried up'.

The substantial quantities of water flowing through the proposed tunnel, planners say, could also be used for cooling purposes by nuclear power
stations, making it possible to build them away from the crowded seashore. - Isracl does not yet have a nuclear power station on the coast-or anywhere else for that matter--but every 'nuclear development' in the country arouses interest, often for the wrong reasons. This was demonstrated once again a few weeks ago when a Dutch newspaper printed a photograph of a tower-like object and captioned it as follows: "A new nuclear energy installation is being completed near Tel Aviv. No details about this installation at the Weizmann Institute are known. However, the great powers are not only interested, but also worried abou Israel's growing atomic strength."

\section{Letter from Israel}

\section{from Nechemia Meyers}

In point of fact, the object shown is the 19-storey Koffler Accelerator Tower, next year to house a 14-UD Pelletron accelerator.

Far from being a secret facility, the Pelletron will be open to scientists from around the world. Indeed the first large international group to visit the site-participants in the recent Third Tandem Accelerator Conference-were there at the same time the Dutch newspaper was making its mistake.

- While Israeli physicists concern themselves, for the most part, with basic research, Israelis in the biomedical field generally concentrate on the solution of day-to-day problems. Such is the case with Professor Bruno Lunenfeld, Director of the Institute of Endocrinology at the Sheba Medical Centre, near Tel Aviv. Professor Lunenfeld, for example, has developed a method that enables previously childless Orthodox Jewish women to have children without violating the tenets of family purity as laid down by traditional Judaism.

For an Orthdox woman, sexual intercourse is only permitted during a limited period each month. It can begin only seven days after the end of her menstrual period, until when she is regarded as 'unclean'. In ordinary circumstances, this does not prevent her from becoming pregnant, but if a woman's menstrual period extends beyond the usual five days, or her menstrual cycle is less than the usual 28 days, her days of greatest fertility may occur during the time when she is 'unclean' and therefore forbidden to her husband.

Professor Lunenfeld found that this problem can almost always be solved, once the religious woman's most fertile days are determined, by giving her an anti-oestrogenic substance known as lomiphene citrate. As a result, ovulation is delayed long enough to occur when the woman is permitted by the laws of family purity to have intercourse. Ironically, this substance was originally developed as a means of birth control, but is now used primarily to induce ovulation in infertile women. Incidentally, Moslem women have also benefited from the treatment. Subject to even more severe laws of purity than are their Jewish sisters, the anti-oestrogenic substance has saved many of them from childlessness, a particularly tragic fate in traditional Moslem society.

- In another part of the Sheba Medical Centre, Dr Dan de-Medina is using the techniques of biofeedback to treat veterans of the Yom Kippur War.

Dr de-Medina, whose professional career began with a cancer research team and later continued in the sphere of memory studies, first delved into biofeedback when on an extended visit to the USA in 1973. He arrived back in this country, fortuitously, shortly before the outbreak of the Yom Kippur War, in the wake of which hundreds of men suffered from posttraumatic neuroses. And in spite of the fact that biofeedback techniques had never previously been used in Israel for the treatment of such neuroses, Dr de-Medina was allowed to use them with some of the badly shaken war veterans.

He found, as did others dealing with this problem, that it was more common and more severe than it had been after previous wars, presumably because the fighting had lasted longer and because the outcome had been less clear-cut (the euphoria of a great victory apparently has a healing effect). The patients sent by the army to $\mathrm{Dr}$ de-Medina generally returned to relative normality more quickly than those treated by other techniques, some of which, unlike biofeedback, involve the possible creation of drug dependence.

The method used by Dr de-Medina (and overseas practitioners) is quite simple. It involves connecting up the patient to a 'Galvanic Skin Response Feedback' instrument, not unlike a lie detector, which registers anxiety on a scale or by the sounding of a siren. After a period of conditioning, usually involving some 20 sessions, the patient finds he is able by his own efforts to reduce the number registered on the scale or the pitch of the siren and, almost as a side effect, to lessen his sense of anxiety. Finally, he gains a conditioned reflex whereby anxiety is switched off, without the benefit of the instrument. 